\title{
APHRODITE OF THE DAWN: INDO-EUROPEAN HERITAGE IN GREEK DIVINE EPITHETS AND THEONYMS ${ }^{1}$
}

\author{
DANIEL KÖLLIGAN \\ University of Cologne (Germany)
}

\begin{abstract}
Aphrodite, originally an epithet of PIE *h $h_{2} e ́ u s o ̄ s$, has taken over numerous features of the goddess of dawn. Like the Vedic Ușas she is the 'daughter of the sky'. She is connected with the calm of the sea $(\gamma \alpha \lambda \eta \dot{v \eta})$ and a rescuer of seafarers, a function fulfilled by Ușas' suitors in Vedic mythology. Her name may derive from * $a b^{h} r_{0}-d i h_{2}$-to'shining up from the mist/foam'. \$2.1 The epithets of Aphrodite made up of or including colour terms ( $\chi \rho v \sigma \eta ́ s, ~ \chi \rho v \sigma o \sigma \tau \varepsilon \dot{\varphi} \varphi \alpha v o \varsigma$, etc.) may refer to her original character as personification of dawn. \$2.2 Her

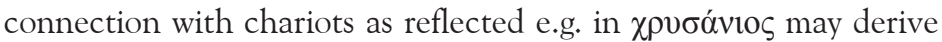
from her association with the chariot of the sun. This could also be

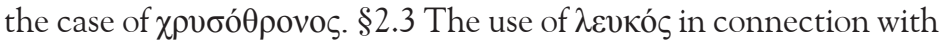
Aphrodite may be compared to Ved. rocamāna-, said of Ușas. \$2.4 Her

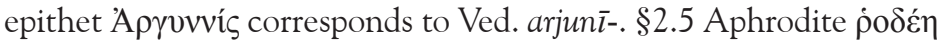

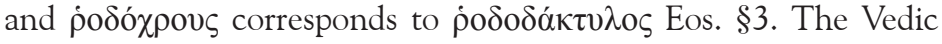
dawn-cows can be compared with the cows of Helios on Thrinakia. The epic epithets $\bar{\varepsilon} \lambda \lambda_{1} \xi$ and $\dot{\varepsilon} \lambda \iota \kappa о \beta \lambda \varepsilon \dot{\varepsilon} \varphi \rho \rho \varsigma$ may refer to the celestial

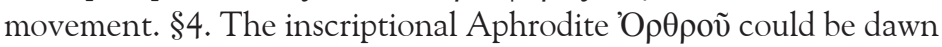
or the morning star as daughter of the morning twilight and may be

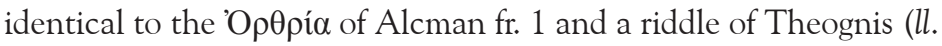

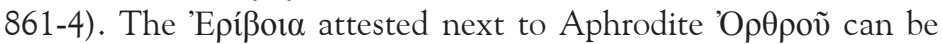
understood as the one 'rich in dawn-cows'.
\end{abstract}

KEY WORDS: Aphrodite and the Vedic Ușas; goddess of dawn and morning star; divine epithets and theonyms.

1 This paper was written in the framework of a two-year project funded by the DAAD, "Divine Epithets in Ancient Greece (Laconia, Aiolis)" (2011-12), a collaboration of the Dept. of Linguistics of the University of Cologne and the Istituto di Filologia classica e Papirologia of the Università Cattolica del Sacro Cuore (Milan). I would like to thank Prof. Dr. J. L. García Ramón, Dr. A. Vegas, Dr. P. Schmitz (Cologne), Dr. N. Guilleux (Caen), Dr. A. Filoni (Milan) and Dr. J. M. Macedo (São Paulo) for their helpful critique and remarks. 


\section{Aphrodite, heiress to the PIE goddess of dawn}

Since Dickmann Boedeker (1974) and Dunkel (1988) it has been a communis opinio that the Greek goddess Aphrodite has adopted features of the Proto-Indo-European (PIE) goddess of dawn, sharing in this inheritance with Eos $<$ PIE * he eusốs and probably Helena, as well. ${ }^{2}$ Numerous features of Aphrodite point in this direction, e.g. the designation as *diuós $d^{h} u g h{ }_{2}$ têr 'daughter of the sky(-god)' found in the Rig-Veda (RV) as divó duhit ầ, usually Ușấs 'dawn', ${ }^{3}$ which

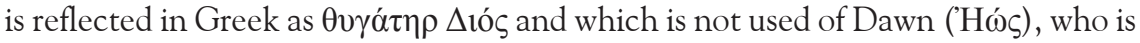
the daughter of Hyperion (Hes. Th. 371-74, h. Hom. 31.6), but of other goddesses like Athene (Hes. Sc. 197), Artemis (Alkm. 27.1, 28), and the Muses (Il. 2.491, Od. 1.10, Hes. Th. 76), and also of Aphrodite (h. Aphr. 81 et passim). ${ }^{4}$ The epithet

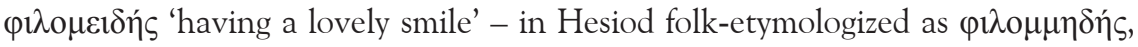
since in Greek myth Aphrodite was born from Ouranos' $\mu \eta \dot{ } \delta \varepsilon \alpha$ 'genitals's - is almost exclusively used of Aphrodite ${ }^{6}$ and recalls the frequent co-occurence of Vedic smi 'to smile' and $U s \underline{a ́ s}$ in the RV, 7 and like Aphrodite the Vedic goddess of

2 The amount of Semitic inheritance in the make-up of Aphrodite's character will not be dealt with here in detail. Qua goddess of sex she was naturally identified with the Semitic Astarte / Ištar, both having cult centres on Cyprus, both representing the morning and evening star (Eosphoros, Hesperos = Venus), both daughters of the sky (of Ouranos and Anu respectively), etc., cf. also Nagy (1996): 54. The nearly exclusive use of the epithet Oujpavía of Aphrodite occurs in contexts of the interpretatio Graeca of near-eastern models, e.g. the Egyptian Hathor, cf. West (1997): 56, 291f. and Pirenne-Delforge (2005).

3 RV 10.70.6 divó duhitárā (du.) used of dawn and night (ușásanáktā), AV 19.47.5 duhitar diváh used of the night alone ( $r a \bar{t} t r \vec{\imath})$.

4 Nagy (1996): 48f. points out the metrical complementarity of Eos and Aphrodite in Homeric formulaic diction: if verse-final 'Hós is immediately preceded by an epithet, it is

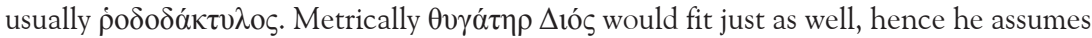
that the latter was ousted by the former in this position. On the other hand, Aphrodite in verse-final position is preceded by $\Delta$ ió $\theta_{0 \gamma \alpha ́} \tau \eta \rho 9 \mathrm{x}$.

5 Cf. for this and other poetic and popular interpretations of names in Greek epic Risch (1947 = Kleine Schriften 294-313). Heubeck (1965 = Kleine Schriften 265-67) assumed the opposite direction of change due to a "humanizing" tendency in Homer, but there

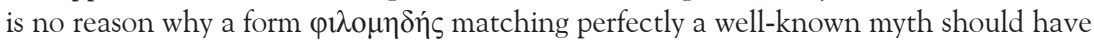
been changed into a euphemistic $\varphi 1 \lambda \mathrm{o} \mu \varepsilon 1 \delta \eta \dot{\zeta}$, which is obviously the forma difficilior. A change $\varphi \imath \lambda о \mu \varepsilon \imath \delta \dot{\varsigma} \rightarrow \varphi \imath \lambda o \mu \eta \delta \eta ் \varsigma$ was assumed by Strunk (1960), too.

6 Only ГАаvкоvó $\mu \eta$ in Hes. Th. 256 seems to be an exception. Note also the depiction

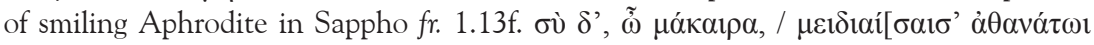
$\pi \rho о \sigma \omega ́ \pi \omega \mathrm{t}$ "But you, blessed one, were smiling with your immortal face".

7 Said once of her mythological father Dyau 'sky', as well, cf. RV 2.4.6 dyaúr iva smáyamāno nábhobhih "like the sky smiling through the cloud", cf. Macdonell 1897 (repr. 2002): 22. 
dawn has a strong sexual aspect as represented in numerous passages, e.g.

RV 1.123 .10

kaníyeva tanúvā śáśadānāmè, éși devi devám íyakșamānam samsmáyamānā yuvatíh purástād, āvir vákșāmsi krṇuṣe vibhātín

Like a maiden, proud of her body, you, o goddess, approach the god desirous of you; smiling, a young woman, you unveil your breasts before him, shining up in the east, ${ }^{8}$

RV 1.92.6

átāriṣma támasas pārám asyá, uṣấ uchántī vayúnā krnoti śriyé chándo ná smayate vibhātì́, suprátīkā saumanasă yājīgah

We have reached the end of this darkness. Shining up Ușas determines the time. Like a seductress she smiles beautifully when she is shining. Of beautiful appearance she has given rise to cheerfulness.

In

\section{RV 10.172.1 à yāhi vánasā sahá come along with your desire}

the hapax vanas- 'desire' is used in combination with Ușas. This feature of dawn's character has been inherited in Greek mythology by both Aphrodite and Eos, and it has been hypostasized into a new personality of her own, Venus, in the Roman world. In Greek mythology, both Eos and Aphrodite have manifold sexual relations with humans: as Eos abducts Orion (Od. 5.121), Tithonos (h. Aphr. 218), Kephalos (Eur. Hipp. 455) and Kleitos (Od. 15.250), Aphrodite abducts Phaethon (Hes. Theog. 990) and falls in love with Adonis (Athen. Deipn. 10.83.34) and Anchises (h. Aphr. 218-38). In the latter case, Aphrodite makes explicit reference to the abduction of Tithonos by Eos as a precedent (Nagy 1996: 49). In the myth of Phaethon the goddesses appear side by side, Eos as his mother, Aphrodite as the one who falls in love with him and abducts him to serve in her temple (cf. Hes. Th. 984-91). It is not unlikely that this version of the story is the result of a reshuffle of the protagonists

8 Cf. Geldner's German translation: "Wie eine Maid, die stolz auf ihren Körper, gehst du, Göttin, zu dem dich begehrenden Gott. Lächelnd enthüllst du, die junge Frau, vor ihm die Brüste, wenn du im Osten erstrahlst." 
after Eos and Aphrodite had become two deities independent from each other. Their co-occurrence in the same myth, however, may point to an earlier state of affairs: in the RV Ușas is both mother and consort or bride to the sun(-god) Sürya, ${ }^{9}$ a situation matching the Greek state of affairs if we interpret Phaethon 'the shining one' as an instantiation of the sun. ${ }^{10}$

Another, though indirect, connection between Aphrodite and the lovely smile may be seen in the fact that she is connected with the calm and shining sea, the $\gamma \alpha \lambda \eta v \eta \eta$

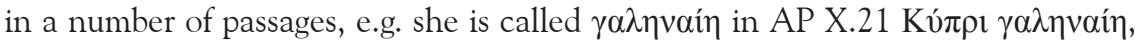
and is responsible for the calm of the sea reported in the story of Dexicreon told by Plutarchus (Aetia Romana et Graeca, Stephanus 303C9) (Pirenne-Delforge, 1994: 433-37):

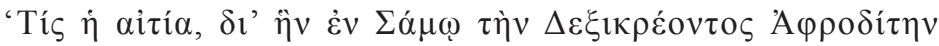

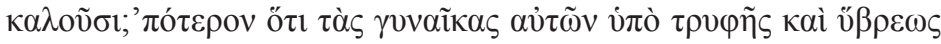

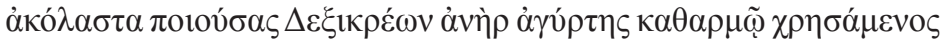

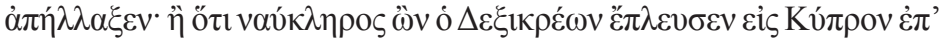

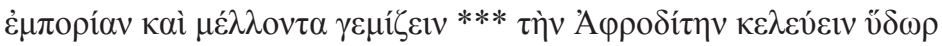

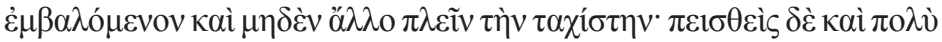

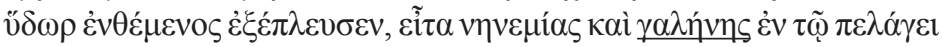

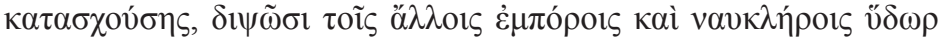

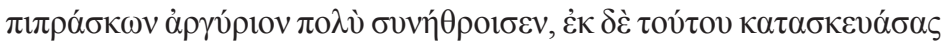

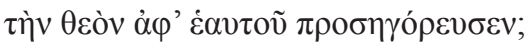

Why is it that on Samos they call upon Aphrodite of Dexicreon? Is this the reason that the women of Samos, by lasciviousness and bawdry falling into great debauchery, were reformed by Dexicreon, a charlatan, using some charms towards them? Or was it because Dexicreon, being the master of a ship, and sailing to Cyprus on a trading voyage, and being about to take in his lading, was commanded by Venus to lade with water and nothing else, and sail back with all possible speed? Being persuaded to do so, he took in much water and

9 E.g. RV 1.115.2 súryo devìm usásam rócamānām máryo ná yớsām abhy eti paścát. "Like a young man goes after a maiden, so Sūrya follows the shining goddess Ușas", 7.78.3 ájījanan súrryam "she (sc. Dawn) has given birth to Sūrya."

10 Cf. Nagy (1996): 49. The same may be true on the cosmological level: in Hes. Th. 378ff. Eos gives birth to the stars, among them the morning star (Eosphoros), which can be identified with Aphrodite, the morning and evening star (Venus). Thanks to A. Filoni for pointing this out to me. 
set sail immediately; still winds and a calm detaining him, he sold his water to merchants and seamen distressed with thirst, whereby he gathered up much money; from which he erected a statue to Venus, and called it by his own name. If this story be true, it is manifest that the Goddess intended not only the enriching of one man, but the saving of many alive by one man (after Goodwin, Plutarch, The Morals, 1878).

Similarly, in a story attributed to Polycharmos of Naukratis (fr. 5 Müller, FHG IV, p. 480), quoted by Athenaios XV, 675f-76c, Aphrodite is responsible for the calm of the sea and the final rescue of the voyagers:

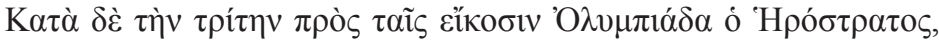

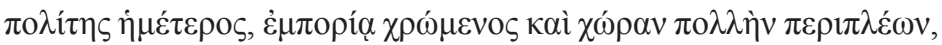

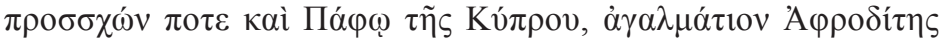

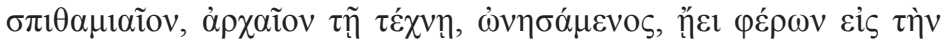

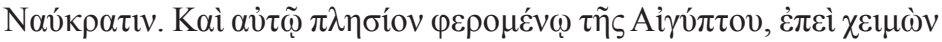

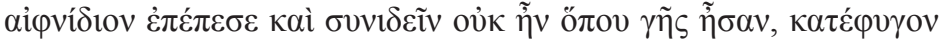

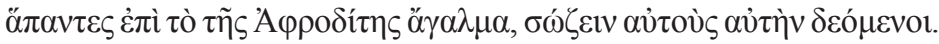

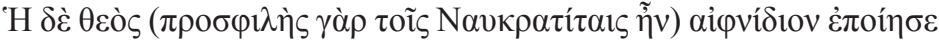

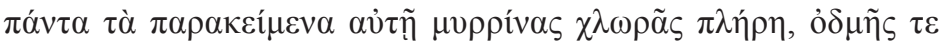

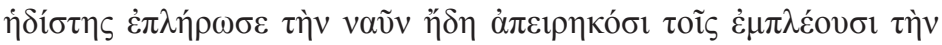

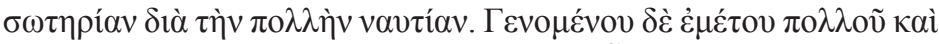

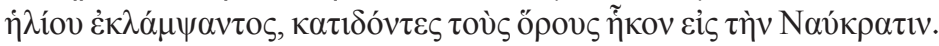

In the 23th Olympiad, Herostratos, one of my co-citizens, a merchant who had already sailed to a number of countries, once came to Paphos on Cyprus and bought a little statue of Aphrodite, a span long, of old workmanship, and then went back on his way to Naukratis. When he approached Egypt, suddenly a storm broke out and they could no longer see where they were (heading); they all took refuge to this statue of Aphrodite, asking her to rescue them. The goddess, who had always loved the people of Naukratis, suddenly transformed everything around her into a green space of myrrhe and filled the whole ship with the sweetest scent, when everybody on board had already despaired of salvation because of the seasickness. After a lot of vomiting had occurred and the sun had begun to shine again, they finally beheld the coastline and reached Naukratis. 
A connection between $\gamma \alpha \lambda \eta \dot{v \eta}$ and the rescue of a seafarer is established also in Od. 5.390 where Ulysses is about to reach safe land. The goddess in question here, however, is not, as one might expect, Aphrodite, but her alter ego, Eos:

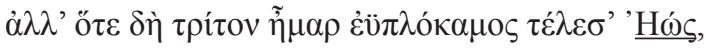

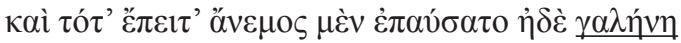

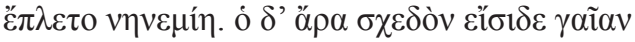

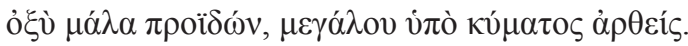

But when fair-haired Dawn brought on the third day and then the wind stopped and there was a windless calm, he beheld a land nearby, looking forward keenly, when a great wave lifted him up.

The imagery of the calm sea and the smiling waters is taken up in the invocation and description of Venus in Lucr. 1.6-9

te, dea, te fugiunt venti, te nubila caeli

adventumque tuum, tibi suavis daedala tellus

summittit flores, tibi rident aequora ponti

placatumque nitet diffuso lumine caelum.

Before thee, Goddess, and thy coming on,

Flee stormy wind and massy cloud away,

For thee the daedal Earth bears scented flowers,

For thee waters of the unvexed deep

Smile, and the hollows of the serene sky

Glow with diffused radiance for thee. (Leonard/Dutton 1916)

Beside this, there is also a morphological connection between Aphrodite and the calm of the sea, since $\gamma \alpha \lambda \eta \dot{v \eta}$ is derived from the same root as $\gamma \varepsilon \dot{\varepsilon} \omega \varsigma$

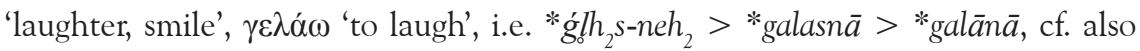
Arm. calr 'laughter'. ${ }^{11}$ The connection is also valid outside Greek: in Vedic religion rescueing seafarers is part of the Aśvins' sive the Nāsatyas' ("Saviours") duties who are intimately related to the dawn-goddess Ușas as her suitors and correspond to the Greek Dioskouroi.

11 The connection between the two concepts can also be seen in the gloss of Hesychius $\gamma \varepsilon \lambda \varepsilon \tilde{\imath} v \cdot \lambda \alpha ́ \mu \pi \varepsilon \imath v . \alpha \dot{\alpha} v \theta \tilde{\imath} v$. 
The etymological proposals to explain the name of Aphrodite itself have centered around these ideas, and the most promising candidates so far - if one does not want to abandon any attempt to find an Indo-European etymology ${ }^{12}-$ seem to be those starting from a second element $* d i h_{2}$-to- 'shining' from *deih 2 $^{-}$(: Gk. $\delta \varepsilon \dot{\alpha} \alpha \alpha /$ - $\tau$ ). While Witzack (1993) assumes a first element * $a b^{h} r o$ - 'strong' as in

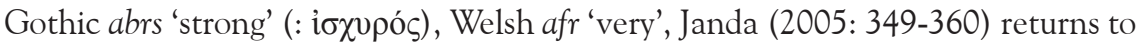
Leo Meyer's view that the first element is nothing else but the well-known Greek word $\dot{\alpha} \varphi \rho o ́ \varsigma$ 'foam', just like Greek learned and popular etymology understood the form in antiquity ${ }^{13}$ - it was only the second element that was no longer connected with the relic-form $\delta \varepsilon \dot{\alpha} \alpha \alpha 1$ - cf. Meyer (1901: 1.160f.): "shining in the foam" ("im Schaume glänzend"), Janda (2005: 360): "who (starts to) shine(s) in the foam" ("die im Schaum aufstrahlt"). ${ }^{14}$ Just like Eos regularly rises from the sea, so Aphrodite is lead by Zephyros across the sea in $h$. Aphr. 1-6:

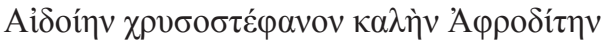

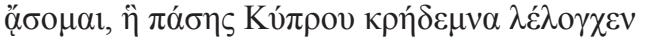

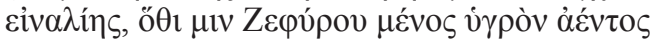

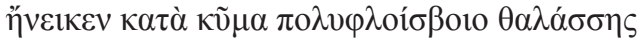

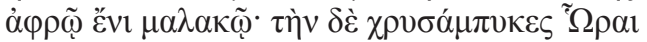

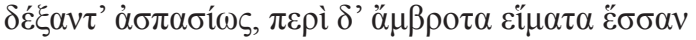

I will sing of that beautiful goddess who wears a crown of gold, revered Aphrodite, who owns on all Cyprus surrounded by sea Each circling head-dress of towers. There strong Zephyr's moist breath through crashing waves conveyed her, amid the soft foam, to shore. The Seasons whose fillets are golden gave her a welcome of joy. (Crudden)

She is described as rising up from the sea in various poems in the AP, e.g.

12 As do e.g. Frisk (1960 s.v.) and West (2000) who opts for a Semitic origin of the name, viz. a title of the goddess 'Aštart, *prāzît 'she of the villages'. On inner-Greek interpretations of the name cf. Pironti (2005).

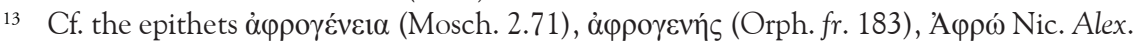
406, etc.

14 A similar image is presented in Il. 1.359 where Thetis rises from the sea "like a cloud"

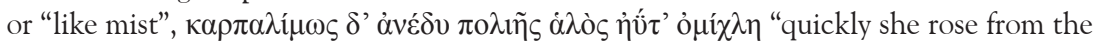
grey sea like a cloud". One may note that à $\varphi \rho \varsigma \varsigma$ 'foam' is usually considered related to Skt. abhrá- 'cloud', cf. Mayrhofer (1992-2001): I. 94 (despite Frisk 1960 s.v.). 


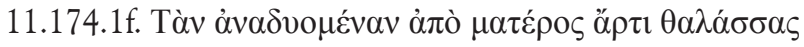

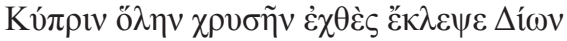

A Cypris made of gold, rising from her mother, the sea, Dion has stolen yesterday,

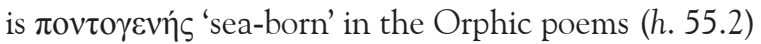

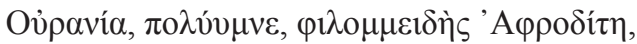

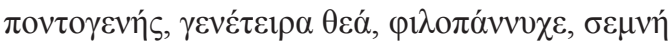

Heavenly, much-sung, lovely smiling Aphrodite, sea-born, goddess of procreation, friend of all-night festivals, revered one.

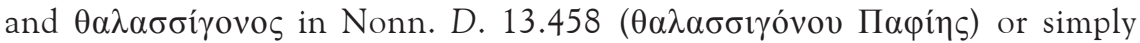

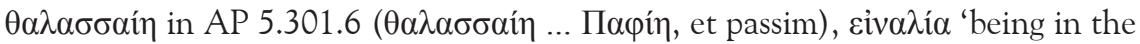

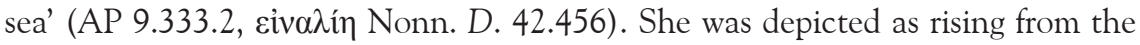

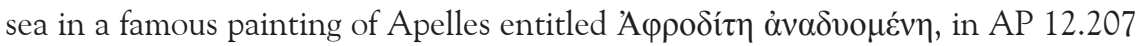

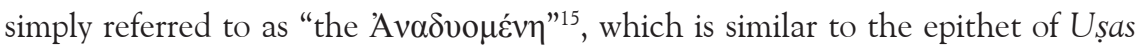
brhat $\bar{l}$ 'the lofty one' (PIE * $b r g^{\prime} h n t i h_{2}$, which survives in the name (and mythological features) of St. Brigid in Old Irish) which probably originally meant 'the rising one' as PIE * $b^{h} e r g^{h}$ - is used in this sense of the moon and the stars in Hittite park-, e.g.

takku ${ }^{\text {Mu }}$ wānuppaštaluš arha pár-ki-ia-an-ta-ri

if the w.-stars rise (and then converge)

(KUB 8.16:3-4+ KUB 8.24 rev. 4-5),

$\mathrm{U}_{4} \cdot \mathrm{SAKAR}-a \check{s}$ pár-ki-i-ia-at

the moon crescent arose(?)

(KUB 57.66 iii 16) (cf. Güterbock/ Hoffner 1997 s.v.)

and of the sun and the moon in Tocharian (B) pärk-, e.g.

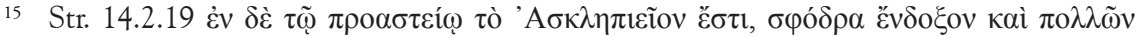

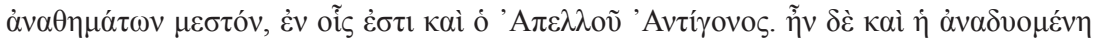
'A euntem e mari divus Augustus dicavit in delubro patris Caesaris, quae anadyomene vocatur, versibus Graecis tantopere dum laudatur, aevis victa, sed inlustrata. 
kauc ka kaum [sai] pärkawo

high had the sun risen,

parka meñe wnolmentsa täñ

the moon rose over thy creatures

(cf. Adams 1999 s.v., Janda 2010: 245).

Her connection with the sea is also evidenced by epithets like $\varepsilon v 0 \pi \lambda o 1 \alpha$ 'securing safe

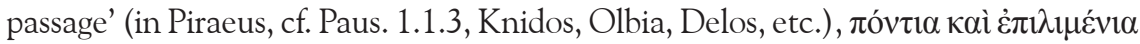
'protectress of the sea and harbour' in Hermione (Paus. 2.34.11) ${ }^{16}$, and $\theta \alpha \lambda \alpha \sigma \sigma \alpha i ́ \eta .{ }^{17}$

In Greek myth itself Aphrodite is literally the daughter of 'heaven', the god Uranos. In his Theogony Hesiod describes how she was born when Kronos - pro-

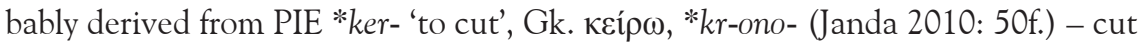
off Uranos' genitals and threw them into the sea, where from the foam (: $\left.\dot{\alpha} \varphi \rho{ }^{\prime} \varsigma\right)$ Aphrodite was born. ${ }^{18}$ This myth might be related to the slaying of Vrtra (and Vala) by Indra and the subsequent release of the light (Janda 2010: 60f., 243ff.) as in

RV 8.3.20

nír agnáyo rurucur nír u súryo, níh soma indriyó rásạ̣ nír antárikṣād adhamo mahám áhim, krșé tád indra paúmsyam

The fires came to light and the sun and the soma, Indra's drink. Away from the sky you blew the great dragon, this manly deed you have done, o Indra,

and in

16 A

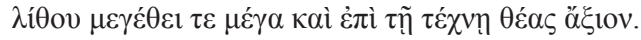

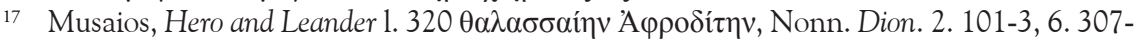
9, 7. 226-32, 13. 60-2, 39. 263-66). Cf. Pirenne-Delforge (1994: 186f.).

18 Gk. oủpavós is usually considered an old epithet of *diếus, the PIE deified sky, for which various etymological proposals have been put forward, either equating it with the Indic Varuna-, PIE *ueruno-/uorunno- from *uer- 'to cover, enclose' (: Skt. var-, prs. vrnóti 'enclose, fence in, hold back, cover'), cf. Dunkel (1988: 3), or connecting it with PIE * $h_{2}$ uers- 'rain' as first proposed by Bopp (1861: $\left.453 \mathrm{fn} .3\right)$, maybe used metaphorically as 'to impregnate' (cf. Peters 1993) or, as per Janda (2004) and Janda (2010: 48-50), as *uorsmn-ó- 'the one in the height', a derivative of *uersmen- 'height' attested in Skt. varsman- 'height' said of the sky in RV 4.54.4 varsman divah 'the height of the sky'. 
RV 6.17.5

yébhih sứryam uṣásam mandasānó, 'vāsayó 'pa drịhâ̄i dárdrat

inspired by them [sc. the soma drinks] you let shine the sun and the dawn, crushing the citadel.

It is in the light of this IE ancestry of Aphrodite that some of her epithets ${ }^{19}$ attested both in Greek literature and in inscriptions shall be investigated in what follows, namely the colour terms most frequently used in describing her appearance (2),

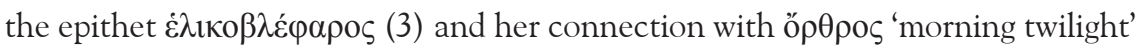
and 'Epíßoıı (4).

\section{The colours of love}

\subsection{Golden Aphrodite:}

Among the commonest epithets applied to Aphrodite are derivatives of

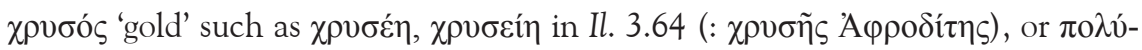

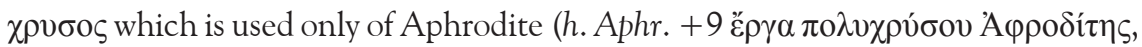
Hes. op. 521, th. 980, sc. 8. 47, fr. 146 [Kinkel]). ${ }^{20}$ She is $\chi \rho v \sigma o ́ \pi \varepsilon \pi \lambda$ os 'wearing a golden garment' in

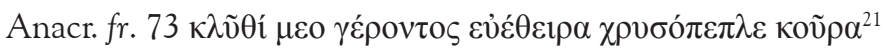

Listen to me, who am an old man, o maiden with beautiful hair, wearing a golden garment,

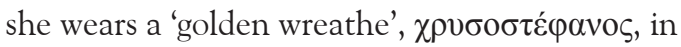

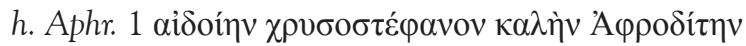

Reverend, beautiful Aphrodite, wearing a golden wreathe,

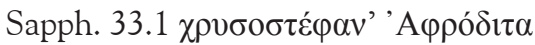

Aphrodite, wearing a golden wreathe,

19 For an exhaustive list of literary epithets cf. Bruchmann (1893).

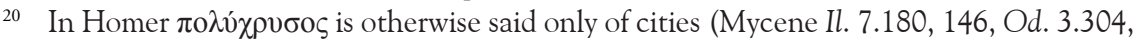
Troy Il. 18.289, Dolon Il. 10.315).

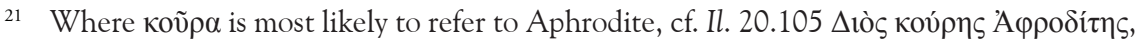

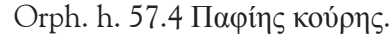


an epithet said of Phoibe ('the bright one', Hes. Th. 136) and Hebe ('youth', Pi. P. 9.109), as well, two central characteristics of the PIE dawn.

Aphrodite's Indic sister Ușas has similar characteristics, she is of golden colour, hiranyavarna- (Dickmann Boedeker 1974: 22), and like Aphrodite she wears 'a shining garment', $22 \mathrm{cf}$.

\section{RV 7.77.2}

viśvam pratīcí sapráthā úd asthād, rúśad váso bíbhratī śukrám aśvait híranyavarṇā sudr'śîkasaṃdrg, gávām mātánetry áhnām aroci

Turning to everyone she has risen in all her breadth, wearing a white shining garment she has begun to shine; golden-coloured, the mother of the cows is beautiful to behold, the leader of the days has begun to shine

RV 3.61.2

úşo devy ámartyā vi bhāhi, candrárathā sūnrítā ìráyantī $a^{\prime}$ tvā vahantu suyámāso áśvā, híranyavarnām prothupájaso yé

Divine, immortal Ușas, shine forth on your splendid chariot, bringing great gifts, may the horses with broad features drive you hither, you of golden colour. ${ }^{23}$

2.2.

Both goddesses are naturally associated with the chariot of the sun-god. Plutarch reports that there was a cult of A

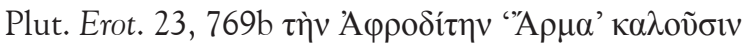

They call Aphrodite 'Arma',

in Sapph. fr. 1 she uses a chariot to descend to earth:

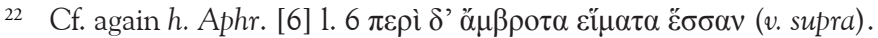

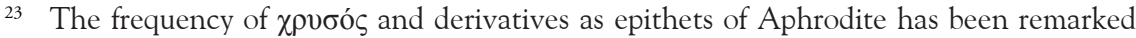
by Meyer (1901: i.161) as well: "Dass sie ursprünglich als 'leuchtend, glänzend' gedacht worden ist, geht am deutlichsten daraus hervor, dass sie oft geradezu als 'die goldene' ... bezeichnet ist." 


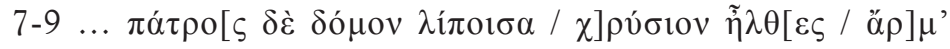
vं $\pi \alpha \sigma \delta \varepsilon[\hat{v} \xi \alpha 1 \sigma \alpha$

Leaving your father's house, you came, having yoked your golden chariot,

and is described as mounting the Graces' chariot in fr. 194 (from Himerius Orat.

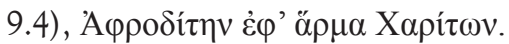

As seen in RV 3.61.2, Ușas uses a 'shining chariot' to ascend into the sky and the chariot used by the Aśvins - her mythological suitors - is made of gold, including a golden seat, hiranyavandhura- ${ }^{24}$, and golden reins (hiranyabhisśsh), cf.

RV 8.5.28

\section{rátham híranyavandhuraṃ, híranyābhīśum aśvinā a'hi stha'tho divispriśam}

.29 hiranyáȳ̄ vām rábhir, īṣááksṣo hiranyáyah ubhácakráhiranyáyā

Mount the chariot with the golden seat, with the golden reins, o As̄vins, that reaches up to the sky. [29] Golden is its back rest, golden is its axle and both wheels are made of gold. ${ }^{25}$

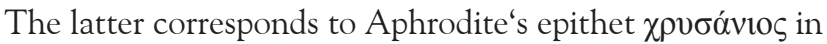

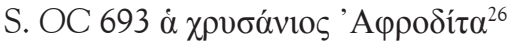

Aphrodite of the golden rein

Similar to her co-heiress Eos who 'has a golden throne' - $\chi \rho v \sigma o ́ \theta \rho o v o \varsigma-(e . g . ~ O d$. 12.142, h. Aphr. 218), an epithet used also of Hera and Artemis, Aphrodite is de-

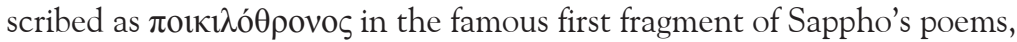

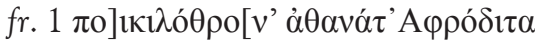

immortal Aphrodite of the colourful throne

24 Also said of Indra's and Vayu's chariot in RV 4.46.4 rátham hiranyavandhuram. In both cases it is described as divispriś- 'reaching the sky'.

25 Also RV 8.22.5 ratho ... hiranyabhïśuh.

26 Also said of Ares, Artemis, and Demeter. 
The much-disputed form has either been interpreted as referring to a $\theta$ óvo Aphrodite, probably making reference to a cult-image of the goddess representing the goddess herself seated on a golden throne, or as referring to the Homeric hapax $\theta \rho o ́ v \alpha$ attested in Il. 22.441, where it seems to indicate 'ornaments', cf.

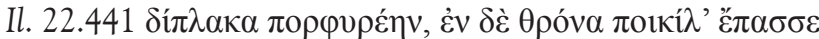

[she was weaving] a red folding robe and worked in elaborate ornaments,

while in later authors it is used in the meaning 'healing / magic herbs':

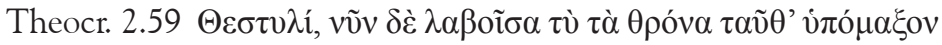

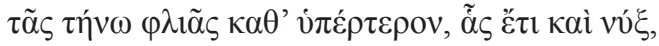

Thestylis, now take these herbs and smear them on his door, the part above the jambs, while it is still night,

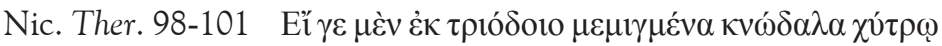

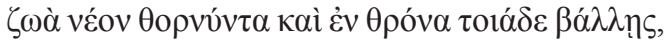

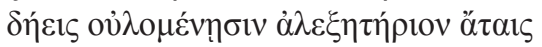

If however you can cast snakes coupled at crossroads, alive and just mating, into a pot, and the following medicaments besides, you have a preventive against deadly disasters (Gow 1953),

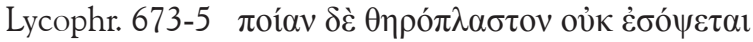

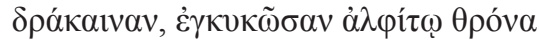

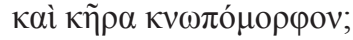

And what she-dragon shall he not behold who moulds wild beasts, who blends with barley drugs and doom of monstrous forms? (Mooney 1979).

Scholia and glosses point into the same direction, cf. the scholion on Theocr. 2.59:

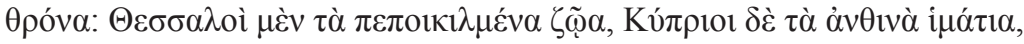

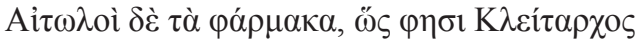

and Hesychius' gloss

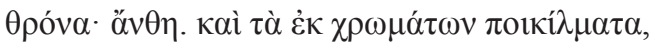


but none of them is necessarily independent from the passage in Homer. In Risch's

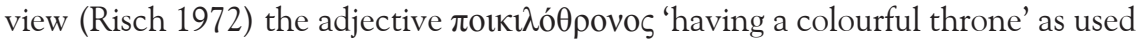
in Sappho is likely to be the older form that was re-analyzed as containing a second element $\theta \rho o ́ v \alpha$ 'ornament, embroidery' before or when it was taken over into hexametric poetry. The equation with pó $\rho \mu \alpha \kappa \alpha$ found in later poetry is likely to rely on a re-interpretation of the otherwise unknown $\theta \rho o ́ v \alpha$ in $I l .22 .441$ due to the frequent co-occurence of the verb $\pi \alpha ́ \sigma \sigma \omega$ 'to embroider; to strew' with $\varphi \alpha \dot{\rho} \rho \mu \alpha \alpha$

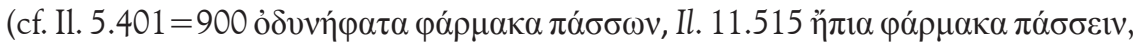
etc.; cf. Risch 1972: 25).

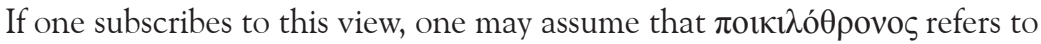
a cult-image of the goddess seated on a throne in her sanctuary. But there may be yet a different possibility: in view of the Vedic description of Ușas and the chariot with a golden seat one may assume that $\theta$ póvo sould not only refer to a 'throne' in a temple, but also to a 'seat' more generally and also to the 'seat' of a chariot. A parallel for this assumption may be the use of díppos which can either refer to the box of the chariot in which both the combatant and the chariot-driver could stand, whence it was used metonymically for the chariot as a whole, or to a seat in

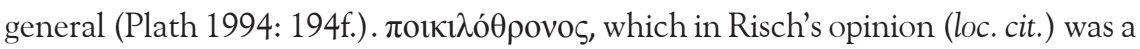
traditional epithet already for Sappho, could thus be a semantic match for the Vedic hiranya-vandhura-. In addition, one may note that Ușas' chariot is supeśas- 'beautifully adorned' (RV 1.49.2), where the element -peś- corresponds etymologically to

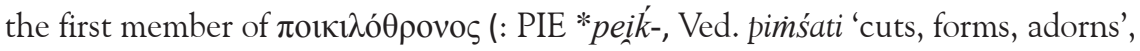
toch. B pinkem 'they paint, write', etc.).

\section{3.}

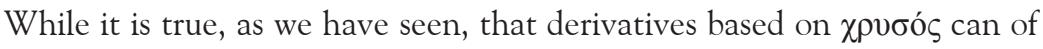
course be applied not only to Aphrodite, but to a number of gods and goddesses, the frequency with which they apply to Aphrodite on the one hand, and the exlusiveness

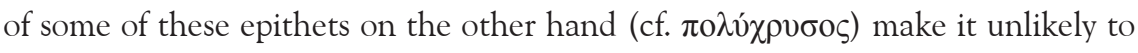
assume that we are dealing here with a meaningless abundance of epitheta ornantia. This is all the more likely when apart from a semantic, there is also a formal match

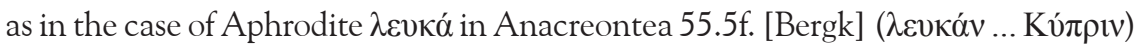
where the same root (: PIE *leuk-) is used of Aphrodite that frequently applies to the Vedic Ușas, too (rocamanā 'shining', e.g. RV 1.115.2). 
2.4 .

An even closer match has been described recently by Janda (2005: 333f., 2006: 16-20) who drew attention to the epithet Aprvvvís which can be compared to arjunī, the feminine form of Skt. arjuna- 'silver-coloured, white', said of Ușas in

\section{RV 1.49 .3}

váyaś cit te patatrino, dvipác cátușpad arjuni

úṣah prärann rờìñ ánu, divo ántebhyas pári

The lively birds, all two-footed and four-footed beings have appeared according to your temporal order from all ends of the sky, o bright-shining Ușas.

The Greek form is attested in the lexicon of Stephanus of Byzantium ( $6 \mathrm{c} . \mathrm{AD})$,

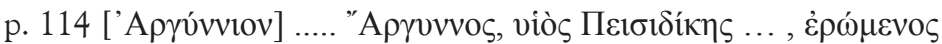

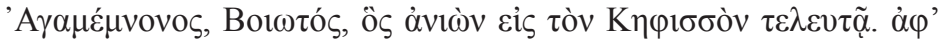

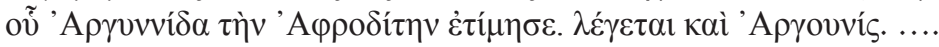
cf. Billerbeck (2008) $)^{27}$

Argynnos, son of Peisidike ... lover of Agamemnon, a Boeotian, who died in the river Kephisos, whence he (Ag.) honoured Aphrodite Argynnis, also called Argunis,

and earlier in a testimonium on Phanocles in Clemens of Alexandria's Protreptikos $(2 / 3$ c. $A D)$, cf.

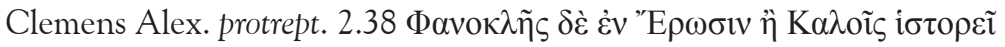

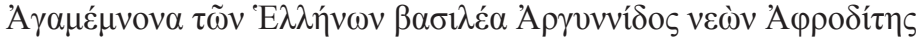

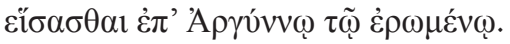

27 Janda loc. cit. only quotes Steph. Byz., but, as the examples show, the form is attested already at an earlier date. 
Phanokles in his "Erotes and Kaloi" tells the story of Agamemnon, king of the Greeks, how he built a temple for Aphrodite Argynnis in memory of his lover Argynnos. ${ }^{28}$

In Athenaios we find

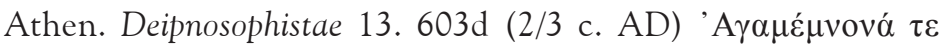

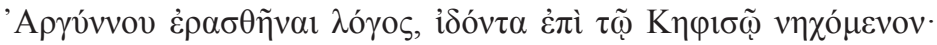

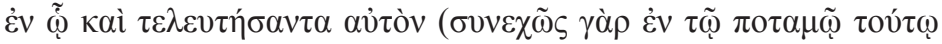

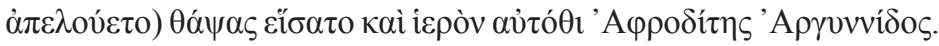

Agamemnon, the story goes, fell in love with Argynnos when he saw him swimming in the river Kephisos; when he died there (for he frequently took a bath in that river), Agamemnon buried him and built a temple on the same spot for Aphrodite Argynnis.

As pointed out by Janda loc. cit., it seems likely that the story of Argynnos has been spun out of the epithet when it was no longer understood in Greek itself. ${ }^{29}$

To Argynnis one may add à $\rho \gamma \rho \rho o ́ \pi \varepsilon \zeta \alpha$ 'with silver feet', said in Homer only

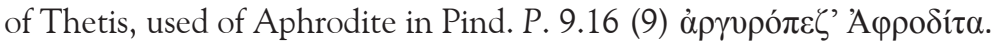

\section{5 .}

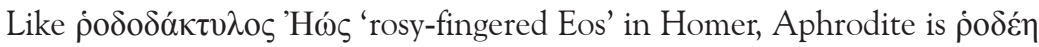

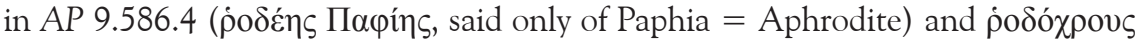
'with rosy skin' in the Anacreontea 53.22 [Bergk] cf.

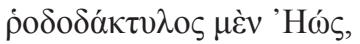

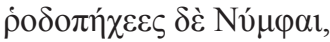

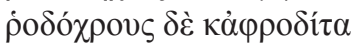

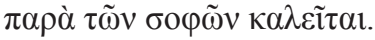

28 This is the text as given by Powell (1925) who bases his corrections on the information given in Athenaios.

29 One might suspect (A. Filoni p.c.) that in an earlier version of the story it was not Agamemnon, but Aphrodite herself who fell in love with Argynnos. This might explain why he was buried next to a temple of hers. 
Eos is called rosy-fingered by the sages, the nymphs are called 'with rosy elbows' and Aphrodite 'with rosy skin'.

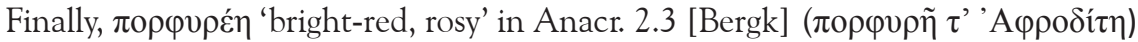
is said only of Aphrodite among the gods.

As we can see, these colour-terms find their correspondances both in Greek in that they are partially common to Eos and to Aphrodite and in Vedic where Ușas is described with etymologically and/or semantically matching terms.

\section{Cows on the move}

It is well-known that one of the forms the PIE goddess of dawn could take at least in Vedic mythology is that of the cow. As we saw above in RV 7.77.2, she is the 'mother of the cows' and the one who 'leads / brings on the days', gávām mat netry áhnām, and in RV 7.79.1 she comes along with beautiful cows (susamdrígbhir ukșábhir) who are also simply called usriyās and usrās 'dawn-cows' ("vachesaurorales" in Renou's terms). ${ }^{30}$ In Greek, it is obvious that Helios' cows and sheep, numbering each seven times fifty, represent the single days of the (moon) year, ${ }^{31} \mathrm{cf}$.

Od. 12. $127 \mathrm{ff}$.

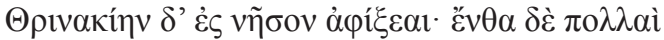

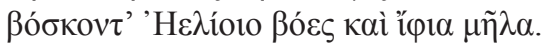

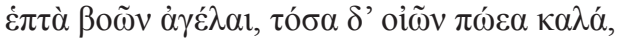

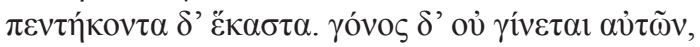

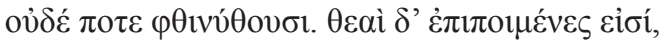

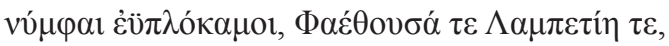

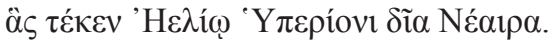

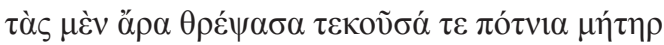

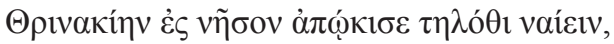

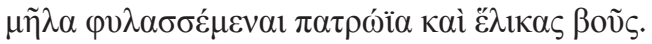

30 E.g. RV 4.5.8, 7.81.2 (led by the Sun itself), cf. Watkins (2009: 225) and EVP 3.4-7, 33.

31 Cf. in this sense Ohlert (1912: 86). Also the cows in the Hymn to Hermes (192-4) are probably related to this, cf. Ohlert loc. cit. If they are not counted and equated with the days of the year, the sun-cows may also represent its rays, as in Vedic and Avestan tradition as well. In the Odyssey Hyperion threatens the gods that if he does not get a compensation for the slaying of his cows, he will have to reside in the underworld (Od. 12.382f.), deprived of his cows, i.e. his rays, cf. Campanile (1986). Cf. also Vegas Sansalvador (2010: 689). 
Then you will reach the island of Thrinakia. There many cows and fat sheep of Helios graze, seven herds of cattle and as much fine flocks of sheep, fifty in each. They have no offspring nor do they ever perish. Goddesses are their shepherds, nymphs with beautiful hair, Phaethousa and Lampetiê whom divine Neaira bore for Helios Hyperion, and their lady mother bore and raised them and sent them off to live far away on the island of Thrinakia to guard their father's sheep and winding cattle.

The riddle expressed in "they have no offspring nor do they ever perish" does not simply refer to divine immortality, but to the repetition of the celestial phenomena that constantly renew themselves, an idea probably also represented

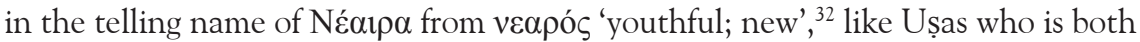
'old' and 'young' in RV 3.61.1 purāṇ̂́ devi yuvatíh, and asked to shine navyasi 'anew, again' in the same hymn v. $3 .^{33}$

The troublesome epithet $\varepsilon \bar{\lambda} \lambda \xi$ said of cows may in this light be understood as referring to that very same movement of dawn and sun, winding their way ( $\varepsilon i \lambda \varepsilon \dot{\varepsilon} \omega$, PIE *uel-, arm. gelowm, lat. volvo) through the sky each day. ${ }^{34}$ The same image, expressed by means of vart 'to turn' (: lat. verto) is attested also for the Vedic Ușas who is invoked to 'roll like a wheel' across the sky:

32 Cf. for the derivation Risch (1974: 138).

33 The solution of the riddle was known in antiquity, cf. fr. 175 of Aristotle [Rose] Schol.

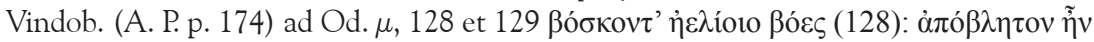

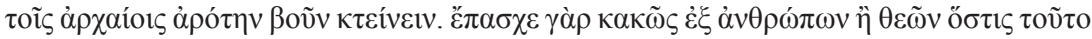

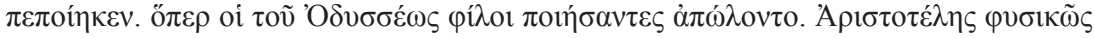

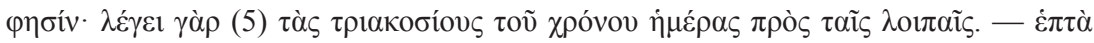

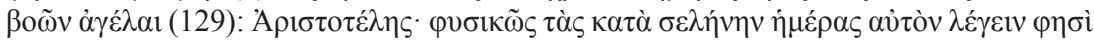

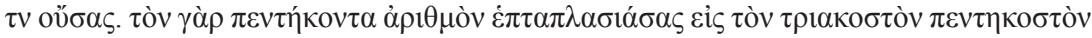

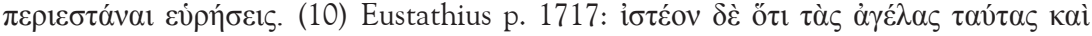

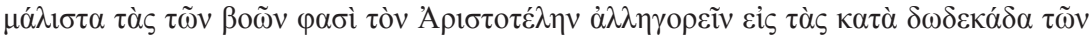

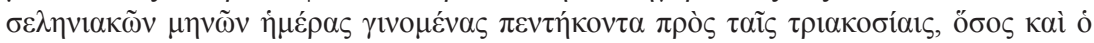

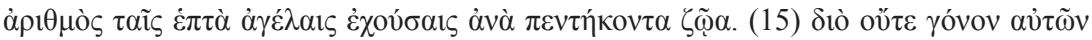

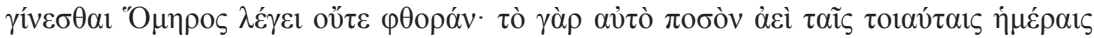
$\mu \varepsilon ́ v \varepsilon 1$. Cf. also West (2008: 370-72).

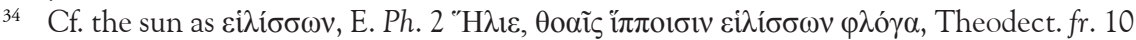

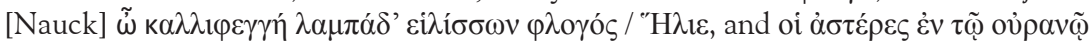

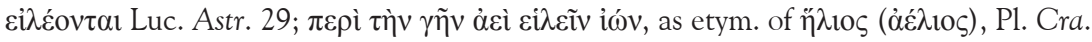
409a. 


\section{RV 3.61.3 cakrám iva navyasy á vavrtsva}

Turn hither anew like a wheel..$^{35}$

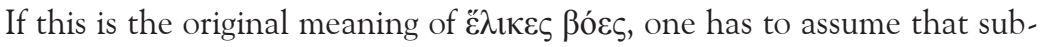
sequently the epithet was reinterpreted as either referring to the movement of cows in a literal sense, or to their having 'curved horns'. The various interpretamenta found for this form in Hesychius and the Homeric scholia point in this direction: ${ }^{36}$

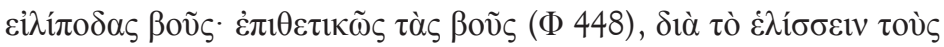

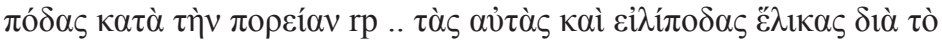

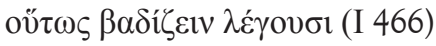

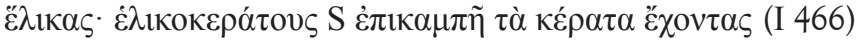

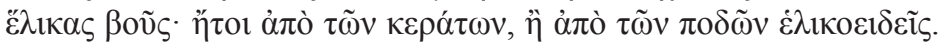

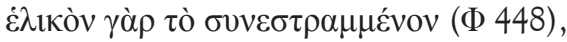

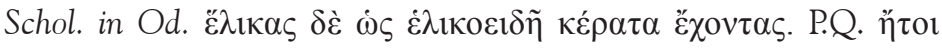

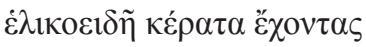

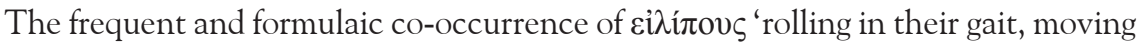

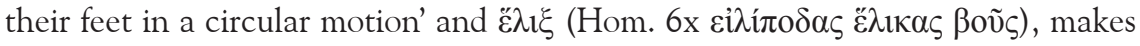
it unlikely that the words are synonyms and the formula may have been the place where $\varepsilon \lambda_{1} \xi \xi$ was reinterpreted as a synonym of $\varepsilon i \lambda i \operatorname{rov}$. Since Helios' cows are both

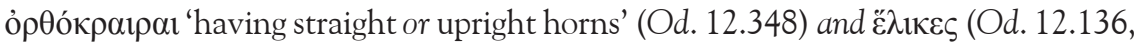
355 ) it seems equally unlikely that they have both (or some of them) curved and (some of them) straight horns. The only other solution is to view the use of this epithet as purely ornamental (Richter 1968), i.e. to assume that its original meaning was no longer understood already in Homeric times. ${ }^{37}$

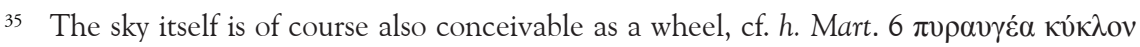

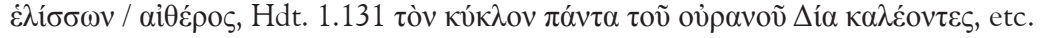

36 For the status quaestionis cf. LfgrE ((Snell 1979) s.v. [O'Sullivan]) where the various proposals made so far are rightly rejected ('black', 'shining', 'with curved horns').

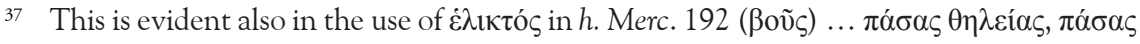

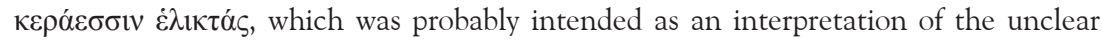
$\varepsilon \check{\lambda} \lambda \xi$. 
It is tempting to view another epithet of Aphrodite in the light of this explanation of $\ddot{\varepsilon} \lambda \xi_{\xi}$, viz. $\dot{\varepsilon} \lambda \iota \kappa o \beta \lambda \varepsilon \dot{\varepsilon} \varphi \alpha \rho \varsigma^{38}{ }^{38}$ which is usually understood as built after

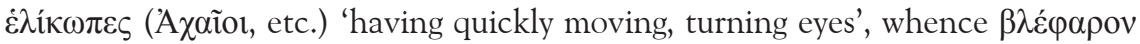
is taken to mean 'eye', not 'eyelid'. Frisk (1960: s.v.) connects $\dot{\varepsilon} \lambda$ iко $\beta \lambda \dot{\varepsilon} \varphi \alpha \rho \circ \varsigma$ with $\ddot{\varepsilon} \lambda \lambda_{1} \xi$ 'spiral', and translates it as 'with curved eyes' ('mit gewundenen, gebogenen Augen'). If, as in the case of $\ddot{\varepsilon} \lambda \lambda_{1} \xi$, the cosmological was the primary meaning, one could assume that from the 'spiralling eye' of dawn - either a description of the rays of dawn, or, more likely, the sun itself - the mundane sense was derived. ${ }^{39}$ The concept of the sun as the 'eye' of the sky is of course well-known, present both in

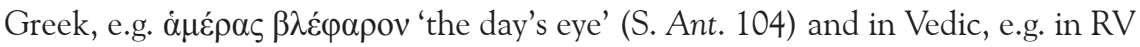
7.77.3 where Ușas brings along 'the gods' eye', devấnām cáksuhn. A converse parallel for the development assumed here could be the case of Old Irish súil 'eye', where the

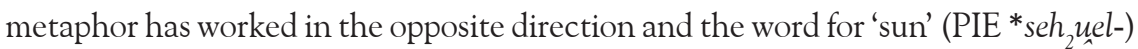
has taken on the meaning of 'eye' in general.

\section{Morning glory}

With the data reviewed so far, it may not come as a surprise to find an "Aphrodite of the Twilight", 'A $\varphi] \rho \circ \delta \varepsilon i \tau \alpha v$ "O $\theta \rho \rho v$, in an inscription from Mytilene (Lesbos) $^{40}$, which may be due either to her original functional equality with dawn or, more likely, to her later identification with the morning star (cf. fn. 1):

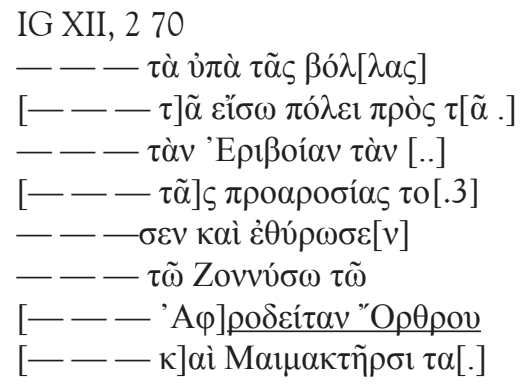

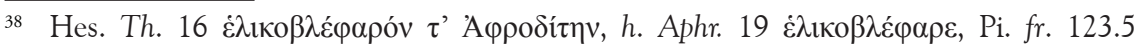

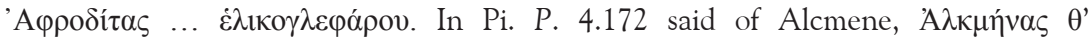

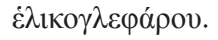

39 Cf. also Verdenius (1972: 231-32) who starts from $\dot{\varepsilon} \lambda i ́ \sigma \sigma \omega$ 'turn, roll, spiral' $\rightarrow$ 'with rolling eyes' $\rightarrow$ 'with flashing eyes'.

40 Dated by Hodot (1990: 276) as $2^{\text {nd }}$ or $3^{\text {rd }}$ c. AD. 


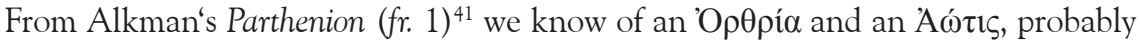
names of one and the same goddess of unclear identity:

Alc. fr. $1.60 \mathrm{ff}$.

$\tau \alpha \grave{~ \Pi \varepsilon \lambda \eta \alpha ́ \delta \varepsilon \varsigma ~ \gamma \alpha ̀ \rho ~} \tilde{\alpha} \mu ı$

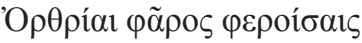

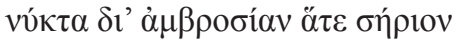

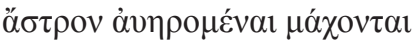

For they, the Pleiades, rising through immortal night like the star

Sirius fight with us while we offer a garment to Orthria,

Alc. fr. $1.87 \mathrm{ff}$.

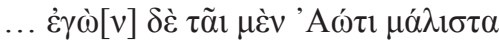

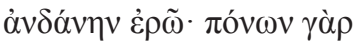

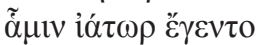

But most of all I want to please Aotis, for she has been our healer of sorrows.

The scene seems to be set in a ceremony just before dawn in which the girls offering a garment to Orthria are in competition with the Pleiades about who is more beautiful. If Aphrodite is the 'daughter of 'O $\rho \theta \rho o \varsigma^{\prime}$ ' as in IG XII, 2 70, she might equally

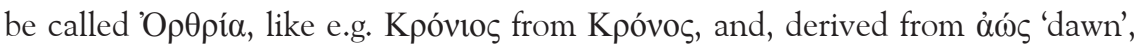
Á́ $\tau \iota \varsigma$. Since ő $\rho \rho \rho \varsigma$ is the time just before daybreak, ${ }^{42}$ a designation of dawn as his daughter seems quite fitting.

According to Calame (1977: II.119ff.), though, Orthria is to be equated with Helena, who was revered as a goddess in Sparta (Hinge 2006: 290). If this interpretation is correct, one should note that Helena, as argued by Jamison (2001) and Janda (2005: 346-48), is one of the "descendants" of PIE * he eusōs in Greek, probably the one who 'chooses' (: *uelh $\left.{ }^{-}\right)^{43}$ her husband (: Skt. svayamvara-

41 For a basic overview over the issues of this fragment cf. still Schwenn (1937).

42 Etymologically probably 'the time of the growing light', *uord ${ }^{h}-o_{-}$, skt. vardh 'grow', cf. Frisk (1960) s.v., separate from ỏ $\rho \theta$ ó $\varsigma^{\prime}$ 'upright' < ${ }^{*} H o r H d^{h} u o-$, skt. $\bar{u} r d h v a-$, lat. arduus, cf. Vegas Sansalvador (2006).

43 Beside the form with spiritus asper, there is a dedication to Fed $\varepsilon \dot{v} \alpha \mathbf{l}$ in Laconian, cf. Laneres (2007). The form could thus go back to either *su- or *u-, for asper from

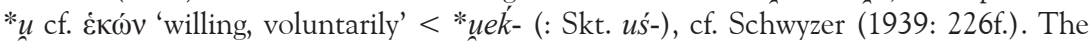
difference in anlaut in FE $\lambda \dot{\varepsilon} v \alpha 1$ and 'E $\mathrm{\lambda} \varepsilon \dot{v} \eta \eta$ has given rise to various interpretations, either assuming the existence of two different goddesses *seleneh, and *sueleneh, 
'choosing for oneself' which is done by Süryā the 'sun-maiden', epitome of the bride, i.e. Ușas), cf. Eur. IA 68-71

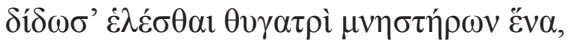

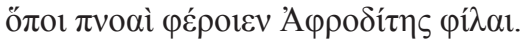

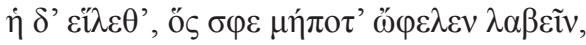

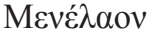

(Her father Tyndareos) allowed his daughter to choose one of her suitors, wherever the lovely winds of Aphrodite might carry her. And she chose Menelaos - would she have never taken him!

ỏ $\rho \rho \rho^{\prime} \alpha$, used as an adjective, also occurs in Theognis' enigmatic lines

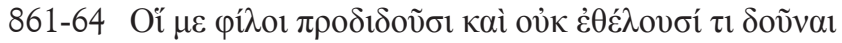

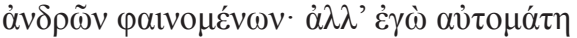

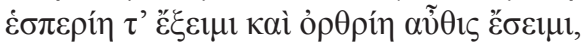

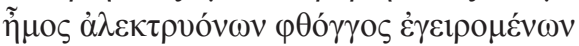

My friends forsake me and do not want to give anything, when men appear. But of my own accord I will go out in the evening and come back at dawn, when the cocks awaken and crow.

The numerous interpretations that have been given for this passage, summarized in Labarbe (1992), are unsatisfactory. ${ }^{44}$ While West's account of it (1974: 160) seems reasonable in itself - a person in the position of a beggar, maybe the owner's wife or daughter who has to leave when his friends arrive for a symposion -, one might speculate that this passage is a mocking description of dawn and the sun, forsaken by her 'friends', i.e. the moon and the stars who disappear when dawn and men appear, both going about their daily business. The sun will "go out", leaving its chariot, i.e. set, and rise again "in the morning" (oj $\theta \rho$ ín) at first cockcrow. ${ }^{45}$

(Skutsch 1987) that merged in Greek, or of two different epithets of PIE dawn that were confused in Greek (Jackson 2006).

44 Cf. Gerber (1999: 299) who classifies Labarbe's identification of the speaker as an owl as "no less bizarre" than the previous attempts.

45 A picture similar to the one in Ov. Metam. 2.111-115 Dumque ea magnanimus Phaethon miratur opusque / perspicit, ecce vigil nitido patefecit ab ortu / purpureas Aurora fores et plena rosarum / atria: diffugiunt stellae, quarum agmina cogit / Lucifer et caeli 
It seems unlikely to be coincidental that next to the 'A $\varphi] \rho \circ \delta \varepsilon i$ í $\alpha v$ "O $\rho \theta \rho \circ v$ we find 'Epıßoí $\alpha v$ in the same inscription. Taken by itself, the form seems to mean

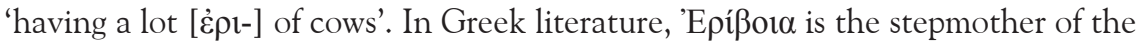
Aloades who held Ares captive (Il. 5.389f.) and the daughter of Alkathoos, wife of Telamon and mother of Aias in

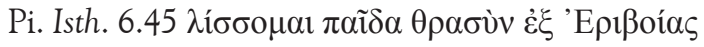

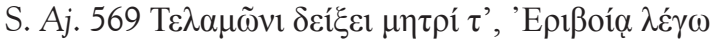

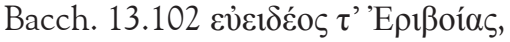

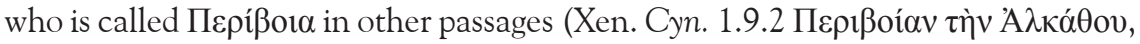

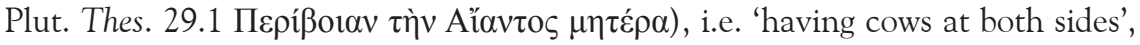
which in our interpretation would refer to dawn and dusk, or 'having many cows' with $\pi \varepsilon \rho 1-$ in an elative sense (Kamptz 1982: 90).

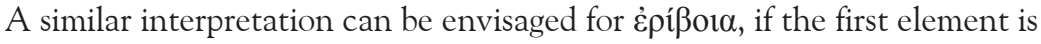
taken in its etymological sense 'at the top' or 'high', as argued by Willi (1999), cf. Luw. šarri 'above' and the Lycian preverb hri 'up', which go back to the locative of a PIE root-noun *sēr 'top', cf. Hitt. šarā 'upward' and the Greek place name 'Píov derived from a denominal adjective *sriyos and probably elliptical from * píov ópos 'high mountain'. PIE *seri 'at the top' would yield Gk. غ́pt- in a psilotic dialect such as that of the Homeric epics. The original meaning 'high' can still be seen in غ́pt-

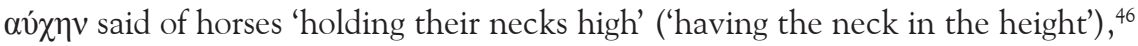

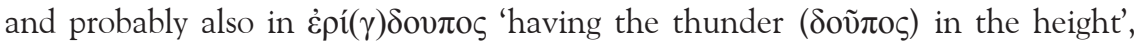

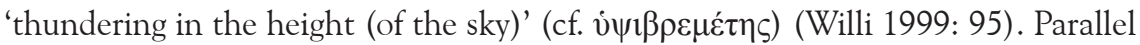
to this, દepíßot $\alpha$ could mean 'having cows in the height (of the sky)', which would be a fitting description of dawn, as we have seen.

Stripped of its cosmological context, the form of course means 'rich in cattle' (usually as a dowry). Both interpretations are present in Hesychius' gloss

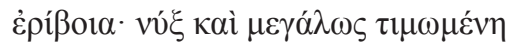

statione novissimus exit. "While aspiring Phaethon admired the glittering chariot and its workmanship, the vigilant Aurora opened forth her purple portals from the ruddy east, disclosing halls replete with roses. All the stars took flight, while Lucifer, the last to quit his vigil, gathered that great host and disappeared from his celestial watch." (B. More).

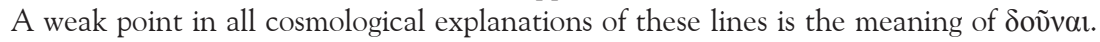
Could dawn be posing as a beggar here?

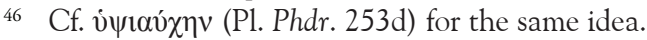


and while the latter is clearly the result of understanding the compound as

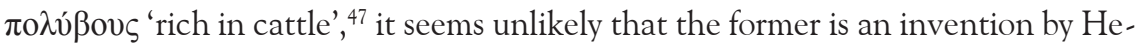
sychius himself, unless one assumes a folk-etymology connecting it with ěp६ßos. If not, and if ésíßoı does indeed refer to dawn, the interpretamentum vó $\xi$ would seem to make sense especially if one assumes the older meaning 'twilight' for vó $\xi$ as in

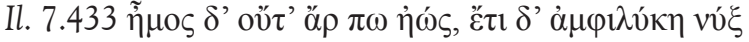

when it was not yet dawn, but the night was still between dark and light (after Murray-Wyatt)

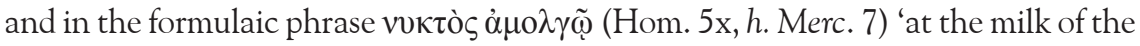
twilight', as pointed out recently by Watkins (2009): 'Epíßot $\alpha$ the 'twilight' brings along her cows at dawn like the Vedic Ușas.

So far we have tacitly assumed that the second element of $\dot{\varepsilon} \rho i \beta o r \alpha$ is the word for 'cow', and this has indeed been the usual interpretation put forward in the literature, also in the case of 'Hepíßot $\alpha$ (Il. 5.389) which contains a different first

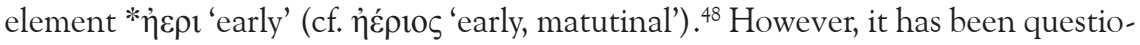
ned by Leukart (1994: $62+\mathrm{fn} .47)$ who interprets -ot $\alpha$ as a secondary feminine

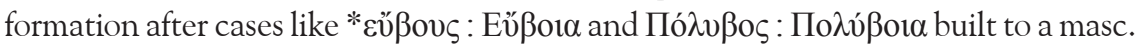

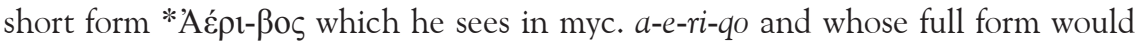
be a-e-ri-qo-ta with a second element /-gwotas/ 'coming in the morning'. Against this, Hajnal (1992: 285-301) proposes to see a form of öop 'spear' in myc. a-e-ri- (if the preform were *aieri one would expect a spelling $\left.a-j e-^{\circ}\right)$, hence 'killing with the spear' (cf. Il. 21.21 öopı $\theta \varepsilon ı v o \mu \varepsilon ́ v \omega v$ 'killed by the spear'), which is therefore to be left out of the discussion. Leukart's rejection of 'cow' as second element is based on

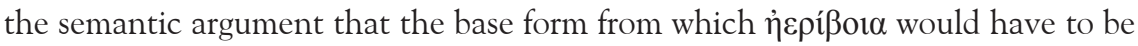
derived, the compound * $\dot{\alpha} \varepsilon \rho i ́ \beta o v \varsigma$, would not make sense ("sinnstörend"). But, as we have seen, 'the cows of dawn' are a well established notion both in Vedic and in Greek literature and therefore a name 'having the cows in the morning' matches the Vedic Ușas bringing along the cows at the beginning of the day. ${ }^{49}$ The only

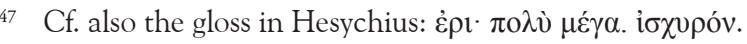

48 E.g. Kamptz (1982: 90): "bei der die Rinder am Morgen sind = die die Rinder am Morgen auf die Weide treibt", Meister (1921: 38) equates the form semantically with A $\lambda \varphi \varepsilon$ бíßota 'bringing lots of cows' in stealing cows or in athletic contests, as names depicting

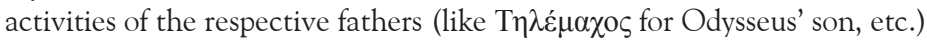

49 The same interpretation would be valid if one assumed Peters' interpretation of $\tilde{\eta} \rho \mathrm{s}$ derived from a locative *awseri 'in the morning' related to the Vedic $r$-stem $u s$ - $r$ - 'mor- 


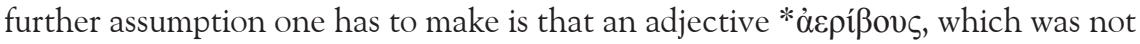
specified for gender, was remarked as feminine as it referred to the female 'daughter of the sky'.50

Thus, if the 'Epíßor $\alpha$ in IG XII, 270 is to be taken as a divine name next to an "Aphrodite of the twilight", its most likely interpretation seems to be 'rich in (dawn) cows', which could subsequently be understood simply as 'rich in cattle (as dowry) ${ }^{51}$

\section{Summary}

The numerous epithets applied to a large extent or exclusively to Aphrodite having formal and / or semantic matches in the Vedic tradition reaffirm the well-established idea that the Greek Aphrodite is, beside Eos and Helena, one of the descendants of PIE * $h_{2}$ eusoss. Based on this notion, a number of epithets

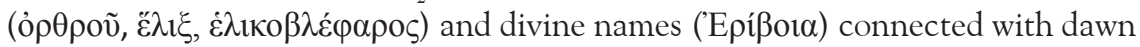
and the sun which are difficult to understand ex graeco ipso may find an explanation.

\section{BIBLIOGRAPHICAL REFERENCES}

Adams, D. Q. 1999. A dictionary of Tocharian B. Amsterdam: Rodopi.

Bechtel, F. 1917. Die historischen Personennamen des Griechischen bis zur Kaiserzeit. Halle/S.: Niemeyer.

Billerbeck, M., 2008. Stephani Byzantii Ethnica: Volumen I: [Alpha-Gamma], Berlin, New York: Walter de Gruyter. Available at: http://www.reference-global.com/ doi/book/10.1515/9783110202816 [accessed March 11, 2011].

Bopp, F. 1861. Vergleichende Grammatik des Sanskrit, Send, Armenischen, Griechischen, Lateinischen, Litauischen, Altslavischen, Gothischen und Deutschen. $2^{\text {nd }}$ ed. Berlin: Dümmler.

ning', loc. usrí (: *h,us-r-i), cf. Peters (1980: 32f.), cf. also Janda (2000: 213-15).

50 N.B. compound adjectives with $\dot{\varepsilon} \rho-$ as first element are usually of only two endings (-o $\varsigma$

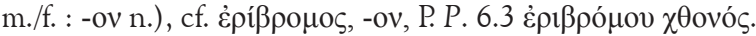

51 That an epithet of dawn can be used as a PN of a mythological character can also be

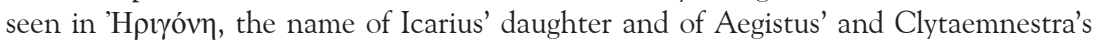
daughter, corresponding to Eos' epithet ìpıréveı (Hom.+) 'early-born', cf. Bechtel (1917: 195). 
BRuchmann, C.F. 1893. Epitheta deorum quae apud poetas graecos leguntur. in: W. H. Roscher (ed.). Ausführliches Lexikon der griechischen und römischen Mythologie. Supplement. Lipsiae: Teubner.

CAlame, C. 1977. Les choeurs de jeunes filles en Grèce archaique. Roma: Ed. dell'Ateneo \& Bizzarri.

Campanile, E. 1986. "I bovi del Sole Iperione", Incontri Linguistici, 11, 25-30.

Dickmann Boedeker, D. 1974. Aphrodite's entry into Greek epic. Leiden: Brill.

Dunkel, G. E. 1988. "Vater Himmels Gattin", Die Sprache, 34, 1-26.

$\mathrm{EVP}=$ ReNOU, L. 1955-. Études védiques et pāniniennes. Paris: de Boccard.

FRISK, H., 1960. Griechisches etymologisches Wörterbuch. Heidelberg: Winter.

Fuchs, G., 2003. Der Becher des Sonnengottes: zur Entwicklung des Motivs "Becher des Zorns". Münster: Lit Verlag.

Gerber, D., 1999. Greek elegiac poetry from the seventh to the fifth centuries BC. Cambridge, MA / London: Harvard University Press.

Gow, A. F. 1953. Nicander. The poems and poetical fragments. Ed. with a transl. and notes. Cambridge: Cambridge University Press.

Güterbock, H. G. \& H. A. Hoffner. 1997. The Hittite Dictionary. P. Chicago: University of Chicago.

HajnaL, I. 1992. "Der mykenische Personenname a-e-ri-qo-ta". In: Olivier, J.-P. (ed.), Mykenaïka. Actes du IXe Colloque internationale sur les textes mycéniens et égéens. Paris: Boccard. 285-301.

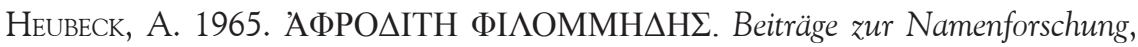
$16,204-206$.

Hinge, G., 2006. Die Sprache Alkmans. Textgeschichte und Sprachgeschichte. Wiesbaden: Reichert.

Hodot, R. 1990. Le dialecte éolien d'Asie. La langue des inscriptions. VII ${ }^{e}$ s. a.C. - IVe p.C. Paris: Éditions Recherche sur les Civilisations.

IsebAert, L. (ed.) 1993. Miscellanea linguistica graeco-latina. Namur: Société des Études Classiques.

JaCKSON, P. 2006. The Transformations of Helen. Indo-European Myth and the Roots of the Trojan Cycle. Dettelbach: Röll.

Jamison, St. 2001. "The Rigvedic Svayamvara? Formulaic Evidenc”. in: K. Karttunen \& P. Koskikallio (eds.), Vidyārnavavandanam. Essays in honour of Asko Parpola. Helskini: Finnish Oriental Society. 303-315. 
JANDA, M. 2000. Eleusis. Das indogermanische Erbe der Mysterien. Innsbruck: Institut für Sprachwissenschaft. . 2004. "Vom blauen Himmel Griechenlands: Oỏpavóৎ", in: Hyllested, A. et al. (eds.), Per Aspera ad Asteriscos. Studia Indogermanica in honorem Jens Elmgård Rasmussen sexagenarii Idibus Martiis anno MMIV. Innsbruck: Institut für Sprachwissenschaft. 235-46.

. 2005. Elysion: Entstehung und Entwicklung der griechischen Religion, Innsbruck: Inst. für Sprache und Literaturen der Universität Innsbruck.

. 2006. "Die indogermanische Göttin der Morgenröte als Namenspatronin", Beiträge zur Namenforschung 41(1), 13-21.

. 2010. Die Musik nach dem Chaos. Innsbruck: Universität Innsbruck, Inst. für Sprachen und Literaturen der Universität Innsbruck.

KAMPTZ, H.V. 1982. Homerische Personennamen: sprachwissenschaftliche und historische Klassifikation. Göttingen: Vandenhoeck \& Ruprecht.

LABARBE, J. 1992. "Identification d'une noctambule (Théognis, 861-864)", in: A. Bodsen, P. Wathelet et al. (eds.) Serta Leodiensia Secunda. Liège: C.I.P.L. 237-45.

Laneres, N. 2007. "Lharpax de Thérapné ou le digamma d'Hélèn", in: M. B. Hatzop-

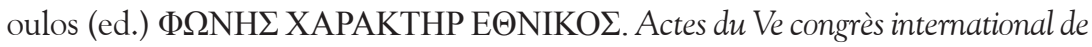
dialectologie grècque (Athènes 28-30 septembre 2006). Paris: de Boccard. 236-69.

Leukart, A., 1994. Die frühgriechischen Nomina auf -tās und -ās. Wien: Verlag der Österreichischen Akademie der Wissenschaften.

LSJ = LidDell, H. G. \& R. ScotT. 1996. A Greek-English lexicon : with a revised supplement. Oxford: Clarendon Press.

Macdonell, A. A. 1897. Vedic Mythology. Straßburg: Trübner. (repr. Delhi 2002: Motilal Banarsidass).

MaYrhofer, M. 1992-2001. Etymologisches Wörterbuch des Altindoarischen. Heidelberg: Winter.

MeIneKe, A. 1849. Stephani Byzantii Ethnicorum quae supersunt. Berolini: Reimer.

MeIster, K. 1921. Die Homerische Kunstsprache. Leipzig: Teubner.

MeYer, L. 1901. Handbuch der griechischen Etymologie. Leipzig: Hirzle.

Mooney, G. W. 1979. The Alexandra of Lycophron. New York: Arno Press.

OHLERT, K. 1912. Rätsel und Rätselspiele der alten Griechen. Berlin: Mayer \& Müller.

PETERS, M. 1980. Untersuchungen zur Vertretung der indogermanischen Laryngale im Griechischen. Wien: Verlag der Österreichischen Akademie der Wissenschaften. 
. 1993. "Ein weiterer Fall für das Rixsche Gesetz". in: Meiser, G. (ed.) Indogermanica et Italica. Festschrift für Helmut Rix zum 65. Geburtstag. Innsbruck: Institut für Sprachwissenschaft. 373-405.

Pirenne-Delforge, V. 1994. L' Aphrodite grecque: contribution à l'étude de ses cultes et de sa personnalité dans le panthéon archaïque et classique. Athènes-Liège: Centre International d'Étude de la Religion Grecque Antique.

. 2005. "Des épiclèses exclusives dans la Grèce polythéiste? L'exemple d'Ourania" in: Belayche, N. (ed.). Nommer les dieux: théonymes, épithètes, épiclèses dans l'antiquité. Turnhout: Brepols. 271-90.

Pironti, G. 2005. "Au nom d'Aphrodite: réflexions sur la figure et le nom de la déesse née de l'aphros" in: Belayche, N. (ed.). Nommer les dieux: théonymes, épithètes, épiclèses dans l'antiquité. Turnhout: Brepols. 129-42.

Plath, R. 1994. Der Streitwagen und seine Teile im frühen Griechischen. Sprachliche Untersuchungen zu den mykenischen Texten und zum homerischen Epos. Nürnberg: Carl.

Powell, J. U. 1925. Collectanea Alexandrina : reliquiae minores poetarum Graecorum aetatis Ptolemaicae 323 - 146 a. C. Epicorum, elegiacorum, lyricorum, ethicorum. Cum epimetris et indice nominum. Oxonii: Clarendon Press.

$\mathrm{RENOU} \rightarrow$ EVP.

RICHTER, W. 1968. Die Landwirtschaft im homerischen Zeitalter. Göttingen: Vandenhoeck \& Ruprecht.

RIsch, E. 1947. "Namensdeutungen und Worterklärungen bei den ältesten griechischen Dichtern" in: A. von Salis (ed.) Eumusia. Festgabe für Ernst Howald. Erlenbach-Zürich: Rentsch. 72-91.

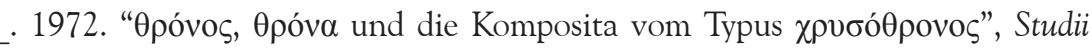
Clasice 14, 17-24. (= Kleine Schriften 354-62).

. 1974. Wortbildung der homerischen Sprache. $2^{\text {nd }}$ ed., Berlin: de Gruyter.

Schwenn, F., 1937. "Zu Alkmans großem Partheneion-Fragment", Rheinisches Museum, 86, 289-315.

SCHWYZER, E., 1939. Griechische Grammatik. vol. 1: Allgemeiner Teil, Lautlehre, Wortbildung, Flexion. München: Beck.

Skutsch, O. 1987. "Helen, Her name and Nature", Journal of Hellenic Studies 107, 188-192.

SNell, B., 1979. Lexikon des frühgriechischen Epos. Göttingen: Vandenhoeck \& Ruprecht. 
StRunk, K. 1960. "Frühe Vokalveränderungen in der griechischen Literatur", Glotta $38,74-89$.

Stüber, K., Zehnder, Th., Remmer, U. 2009 Indogermanische Frauennamen. Heidelberg: Winter.

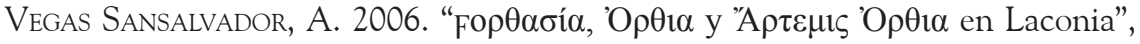
Emerita 64, 275-288.

. 2010. El antropónimo Polideuces. in: F. Cortés Gabaudan, J. V. Méndez Dosuna (eds.), DIC MIHI, MVSA, VIRVM. Homenaje al profesor Antonio López Eire. Salamanca: Ediciones Universidad de Salamanca.

Verdenius, W. J., 1972. "Notes on the Proem of Hesiod's 'Theogony"', Mnemosyne, 25(3), 225-260.

Watkins, C., 2007. "The Golden Bowl: Thoughts on the New Sappho and its Asianic Background”, Classical Antiquity, 26(2), 305-324.

.2009. "The Milk of the Dawn Cows Revisited”, in: K. Yoshida \& B. Vine (eds.), East and West. Papers in Indo-European Studies. Bremen: Hempen. 225-39.

West, M., 1974. Studies in Greek elegy and iambus. Berlin: De Gruyter. . 1997. The East Face of Helicon : west Asiatic elements in Greek poetry and myth. Oxford: Clarendon Press. . 2000. "The Name of Aphrodite", Glotta 76(1-2), 134-38.

. 2008. Indo-European poetry and myth. Oxford: Oxford University Press.

WiLli, A., 1999. "Zur Verwendung und Etymologie von griechisch દ̇pı-”, HS 112 (1), 86-100.

WitcZAK, K. 1993. "Greek Aphrodite and her Indo-European Origin" in: Isebaert 1993, 115-123.

Kölligan, D. Afrodite da aurora: herança indoeuropéia nos epitetos divinos e teônimos gregos.

RESUMO: $§ 1$. Afrodite, originalmente um epíteto do PIE * $h_{2}$ éusōs, incorporou inúmeros aspectos da deusa da aurora. À maneira da Ușas védica, é a "filha do céu", relacionada à calmaria do mar $(\gamma \alpha \lambda \eta \dot{v \eta})$ e à salvadora dos marinheiros, função exercida pelos pretendentes de Ușas na mitologia védica. Seu nome pode derivar de *ab ${ }^{h} r o-d i h_{2}$-to- "brilhando a partir da névoa, ou espuma". § 2.1 Os 
epítetos de Afrodite derivados de nome de cor, ou que o incluem

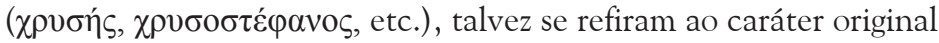
da deusa como personificação da aurora. § 2.2 Sua relação com

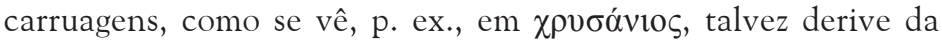
associação da deusa com a carruagem do sol, o que poderia também ser o caso de $\chi \rho v \sigma o ́ \theta \rho o v o s . ~ § 2.3 \mathrm{O}$ uso de $\lambda$ عvкó em conexão com Afrodite pode ser comparado com o véd. rocamāna-, que se diz de Ușas. § 2.4 Seu epíteto Apyvvvís corresponde ao véd. arjunī-. § 2.5

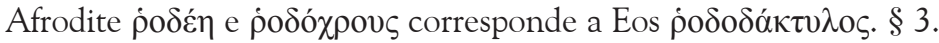
A figura védica das "vacas da aurora" pode ser comparada com a das vacas de Hélio em Trinácia. Os epítetos épicos ع̌ $\bar{\lambda} \xi$ e $\dot{\varepsilon} \lambda ı \kappa o \beta \lambda \varepsilon ́ \varphi \alpha \rho \circ$ talvez se refiram ao movimento celeste. $§ 4$. A Afrodite 'O $\rho \rho \rho \tilde{v}$ da inscrição pode ser a aurora ou a estrela da manhã, como filha da alvorada, e pode equiparar-se ao 'O $\rho \theta \rho i ́ \alpha$ do frg. 1 de Álcman e a um enigma de Teógnis (vv. 861-4). O 'Epíßor $\alpha$ atestado junto a Afrodite 'O $\rho \rho \rho$ ṽ pode ser entendido como "rica em vacas da aurora".

PALAVRAS-CHAVE: Afrodite e a Ușas védica; deusa da aurora e estrela da manhã; epítetos divinos e teônimos. 